\title{
GEOCHEMISTRY AND MINERALOGICAL EVALUATION OF QUARTZITE BEARING KYANITE IN KUTA, NORTHWESTERN NIGERIA.
}

\author{
Omang, B. 0. ${ }^{1}$ and ${ }^{*}$ Alabi, A. A. ${ }^{2}$
}

DOI:http://dx.doi.org/10.4314/ejesm.v4i3.11

Received October 27th 2011; accepted November $5^{\text {th }} 2011$

\begin{abstract}
Kyamite is blue to green triclinic mineral, originated from moderately high pressure and temperature associated with regional metamorphism of politic rocks. Kyanite is associated with minerals like staurolite, andalusite, talc and corundum, and is a member of 1:1 aluminous-silicates. Economic occurrences are of lump massive and lenses with at least 35\% content of $\mathrm{SiO}_{2}$ and $40 \% \mathrm{Al}_{2} \mathrm{O}_{3}$. This present study is necessitated as a result of the industrial applications of kyanite. The Kuta kyanitequartzite form a narrow ridge of about 300 metres high and $6 \mathrm{~km}^{2}$, it intruded into the country rock of mica-schist. AAS and XRD techniques were employed in the determination of chemical and mineralogical composition of ten representative raw and beneficiated kyanite-quartzite samples. Beneficiation was done by electromagnetic and methylene iodide separation techniques. The combined AAS and XRD analyses results show that $\mathrm{Al}_{2} \mathrm{O}_{3}+\mathrm{SiO}_{2}$ constitute $92 \%$ and kyanite alone constitute $55 \%$ of the beneficiated samples, quartz, mulite and silliminite 45\%. Evaluation of the indusrial suitability show inconsistent of the Kuta kyanite with BSI and ASTM standards specification for industrial mineral, it can be use as refractory material based on the alumina content.
\end{abstract}

Keywords: Geochemistry, Mineralogy, Quartzite, Kyanite, Evaluation.

\section{Introduction}

Kyanite originate from moderately high pressure and temperature associated with regional metamorphism of politic sediments (Van Noy, 1970). It is mostly found in gneisses or granite pegmatite and sometimes in quartz veins, it occur in the form of kyanite quartzite and kyanite schist and gneisses. The kyanite quartzites are rocks that contain 15 to $40 \%$ kyanite mineral and usually about $5 \%$ of other minerals such as pyrite, rutile, and mica (Marr, 1992). While kyanite schists and gneisses are very common in highly metamorphosed regions of the Nigeria basement complex (Truswell and Cope, 1963); kyanite occur in quantities ranging from a percent to $2 \%$ to as much as $25 \%$ in gangue of biotite, feldspar, muscovite, garnet, and occasionally hornblende and other common rock forming minerals. Kyanite is however associated with minerals such as staurolite, andalusite, talc and corundum (Carr, 1994).

Generally, kyanite occurs as an elongated "lathlike" crystals and most often in high pressure regional metamorphosed aluminous rocks, and is a member of the sillimanite group of minerals referred to as 1:1 aluminous - silicates. Despite the similarities, each of the minerals in this group has a unique crystalline structures and it is this differing crystal structures that give each mineral its distinctive physical properties. Many of these differences work in favour of kyanite as raw materials additive for refractory and ceramic products (Potter, 1988). Minerologically, kyanite is blue to light green, triclinic mineral, with hardness of 5 parallel to the long axis of the crystal and a hardness of 7 across the long axis of the crystal. There are three types of economic kyanite deposits, these include lump, massive deposits in form of boulders or lenses, disseminates mineral in schist and gneisses and placer or alluvial and beach sand deposits. The most common and usable type are the lump massive and lenses.

kyanite can be used in the raw form or calcined in the manufacture of cements, refractories, castables, and plastic ramming mixes. In most applications kyanite is mixed with clay and other materials, it is also used in the manufacture of tiles and sanitary wares, where its main function is to offset shrinkage and cracking that often result after firing clay.

\footnotetext{
${ }^{1}$ Department of Mineral resource Engineering Technology, Federal Polytechnic Auchi, Edo State Nigeria.

${ }^{2}$ Geology Department Federal University of Technology Minna, Niger State Nigeria.

*Corresponding author: kola_rock@yahoo.com
} 
The results of detailed geochemical and mineralogical of kyanite-quartzite occurrence will surely benefit local source for industrial raw material and contribute to the industrial raw materials inventory of Nigeria.

\section{$\boldsymbol{n}$ - $l o g y$ of the study area}

79 The study area lies between longitudes $6^{\circ} 39^{\prime}$

$\mathrm{E}$ and $6^{\circ} 45^{\prime} \mathrm{E}$ and latitudes $9^{\circ} 48^{\prime} \mathrm{N}$ and $9^{\circ} 56^{\prime} \mathrm{N}$

(Fig 1). It falls within the north basement complex of Nigeria and forms part of the Kusheriki Psammite formation. The Kusheriki Psammite formation includes migmatites and other three members, each of distinctive lithology. These are the quartzites of the Kubo member, the kyanite - schist and quartzites of Tungan Bargwoma member, and the granulitic rocks of Zungeru member, (Truswell and Cope, 1963).

In the study area two principal outcrops of mica-schist and quartzite schist occur, the quartzite which forms a narrow ridge outcrop intruded into the mica-schist at Kuta, where they are over 300meters high and developed in area of about $6 \mathrm{~km}^{2}$ and another rock found in the area is granite gneiss.

\section{Material and Methods}

\section{Sampling and analytical techniques}

Samples of the kyanite-quartzite in Kuta were collected in a network of grid spread over the outcropping area. The sampling interval adopted varied somewhat at different localities under investigation due to differences in the dimension of the outcrops.

Ten representative fresh quartzite samples were crushed, ground and analysed for major and trace elements at the National Steel and Raw Materials Exploration Agency Kaduna Nigeria, using an Alpha 4 Chem. Tech. Atomic Absorption Sepctrometer (AAS), after digestion of the samples in the Department of Geology, Federal University of Technology Minna, Nigeria. Cleaned concentrate of Kyanite was beneficiated by electromagnetic and methylene iodide separation technique. $\mathrm{Si}, \mathrm{Al}, \mathrm{Mn}, \mathrm{Mg}, \mathrm{Ca}$, $\mathrm{Na}$ and $\mathrm{K}$ concentrations in powdered samples were measured with single element light source. Calibration for each element was achieved using four AAS standard solutions of known concentrations. Two consecutive runs were carried out for each measurement and the standard deviation recorded. Elemental values were recalculated to oxides using appropriate colorimetric method. Table 1 shows summary of the result of chemical analyses compared with British standard Institution (BSI) and American Standard (ASTM) in percentage.

Mineralogical compositions of the ground quartzite were analysed using the Philip - PW 1011 model X-ray diffractrometer of the National Steel and Raw Materials Exploration Agency Kaduna, Nigeria. The diffraction patterns were recorded at scan rate of $1^{0} 20 / \mathrm{min} / \mathrm{cm}$ with a Ni - filtered Fe K - alpha radiation. The diffractograms were interpreted by comparing peaks of notable intensities with those of standard minerals established by the Joint Committee on Power Diffraction Standards (JCPD. 1974). The area method also employed in calculating the relative proportion of identified minerals described by Carrol (1971).

\section{Results and Discussion}

The summary of the chemical analysis result of the representative samples is represented in Table 1. An over view of the chemical analysis shows that the average of $\mathrm{Al}_{2} \mathrm{O}_{3}+\mathrm{SiO}_{2}$ in the beneficiated kyanite - quartzite samples constitutes $92.05 \%$. Other oxides range from $1.3 \%$ to trace and comparison of the average chemical composition of Kuta kyanite quartzite with the chemical specification of British and America Standard for industrial application of kyanite (Table. 1) revealed that the Kuta kyanite was at variance with the British, American Standard's specification for industrial application of minimum 56\% allumina $\left(\mathrm{Al}_{2} \mathrm{O}_{3}\right)$ content. It can also not be said to be a total deviation from the aforementioned standards as the major oxides are almost 50\%, and the minor elements are only found in trace amounts.

Results of mineralogical analysis presented show the mineralogical assemblages of both raw kyanite - quartzite samples and beneficiated kyanite - quartzite samples, the minerals present in the samples have been indicated against their diagnostic major peaks (Fig 2). The dominant minerals present in the samples were kyanite $(\mathrm{d}$ $=12.1 \mathrm{~A}, 21.1 \mathrm{~A}, 26.2 \mathrm{~A}, 42.2 \mathrm{~A}, 50.1 \mathrm{~A}, 60.0 \mathrm{~A}$ and 69.1A). Quartz, Sillimanite and mulite occured in trace amounts in the samples. Of all 


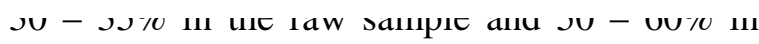
beneficiated samples. It can be seen from the results of the analysis that benification for the removal of muscovite and reduction of hematite is successful, and this would be necessary if the deposit is to be exploited.

\section{Conclusion}

The Chemical and mineralogical analyses after beneficiation shows that the kyanite found in the study area even though not completely consistent with the British and American standard specification for industrial mineral, it can be said to be suitable for use as a refractory material based on the alumina content. Also, according to Chesti (1986) classification, the Kuta Kyanite can be grouped as type III with alumina content of between $45-55 \%$ and can be used for refectories material containing between $40-45 \%$ alumina.

\section{Recommendation}

Based on the chemical and mineralogical results, reserve estimation of the kyanite occurrence in Kuta should be given attention to determine its quantity for economic potential and possible exploration.

\section{References}

Carr, D. D. (1994); Industrial Minerals and

Rocks. $6^{\text {th }}$ ed. Society of Mining Metallurgy and
Exploration, Littleton. Pp 921 - 927.

Carrol, D. I (1971); Clay Mineral; a guide to their X-ray identification. Geology Soc.

of America. Special paper. 126.

Chesti, A. R (1986); Refractory, Manufacture, Properties and Application. Grinadar Publ. (India). August 1986. pp 59 - 57.

JCPDS (1980); Mineral Powder Diffraction File: Vols. I and II Publ. Intern Centre for Diffraction data Parklane U.S.A.

Marr. J. D. (1992); "Geology of the Kyanite Deposits at Willis Mountain Virginia" proceedings, $26^{\text {th }}$ forum on the geology of industrial minerals, P.C. Sweet, ed., Publ. 119. Virginia Division of Mineral resources. Pp 129 134.

Potter, M. J. (1988); "Kyanite and related materials" "Mineral year book" metals and minerals Vol.I US Bureau of Mines pp 577-580. Truswell F. G. and Cope, R. N. (1963); The geology of parts of Niger and Zaria provinces of Northern Nigeria, Geological Surv. Of Nigeria. Bull. 29 pg $9-15$.

Van Noy, R. M. (1970); "Kyanite Resources in Northwestern United State" Report of Investigation 7426, US Bureau of Mines pp 81 82.

Table 1. Average chemical composition of Kuta kyanite - quartzite compare with British and American standard.

\begin{tabular}{|l|l|l|l|l|}
\hline Oxides & $\begin{array}{l}\text { Raw Kuta } \\
\text { Samples \% }\end{array}$ & $\begin{array}{l}\text { Beneficiated } \\
\text { Sample \% }\end{array}$ & $\begin{array}{l}\text { British Standard } \\
\text { Institution (BSI) } \\
\%\end{array}$ & $\begin{array}{l}\text { American } \\
\text { standard } \\
\text { (ASTM) \% }\end{array}$ \\
\hline $\mathrm{SiO}_{2}$ & 46.65 & 43.60 & 42.00 & 39.01 \\
$\mathrm{Al}_{2} \mathrm{O}_{3}$ & 47.67 & 53.45 & 56.00 & 56.50 \\
$\mathrm{Fe}_{2} \mathrm{O}_{3}$ & 1.02 & 0.29 & 1.00 & 0.80 \\
$\mathrm{TiO}_{2}$ & 1.28 & 1.12 & - & 0.18 \\
$\mathrm{CaO}$ & 0.10 & 0.10 & - & 0.09 \\
$\mathrm{MgO}$ & 0.02 & 0.10 & - & 0.02 \\
$\mathrm{Na}_{2} \mathrm{O}$ & 0.01 & 0.10 & - & 0.01 \\
$\mathrm{~K}_{2} \mathrm{O}$ & 0.02 & 0.01 & - & 0.02 \\
$\mathrm{P}_{2} \mathrm{O}_{5}$ & 1.30 & 1.20 & 0.1 & - \\
$\mathrm{LO} \mathrm{I}$ & 1.92 & 0.20 & - & - \\
\hline
\end{tabular}




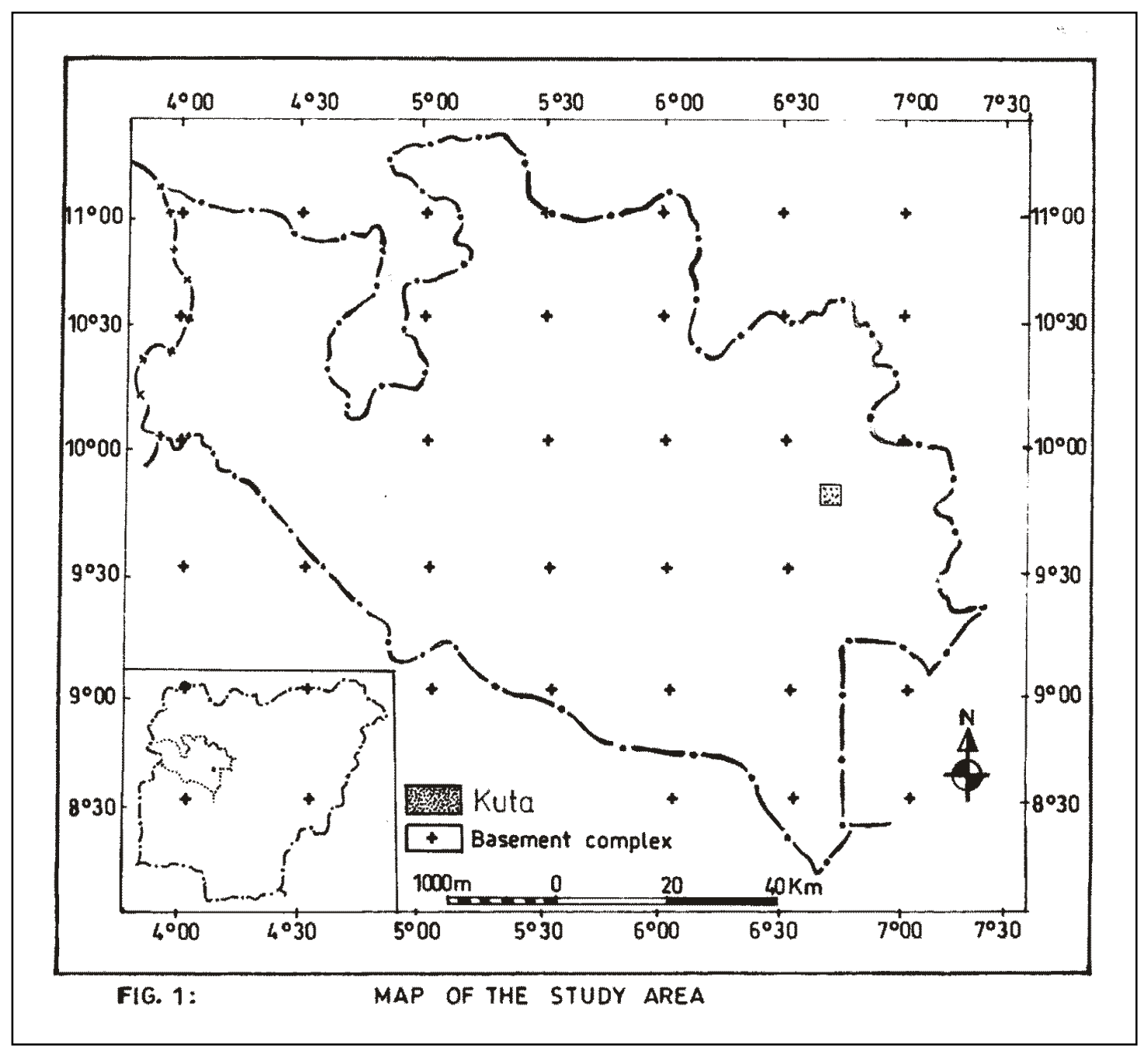



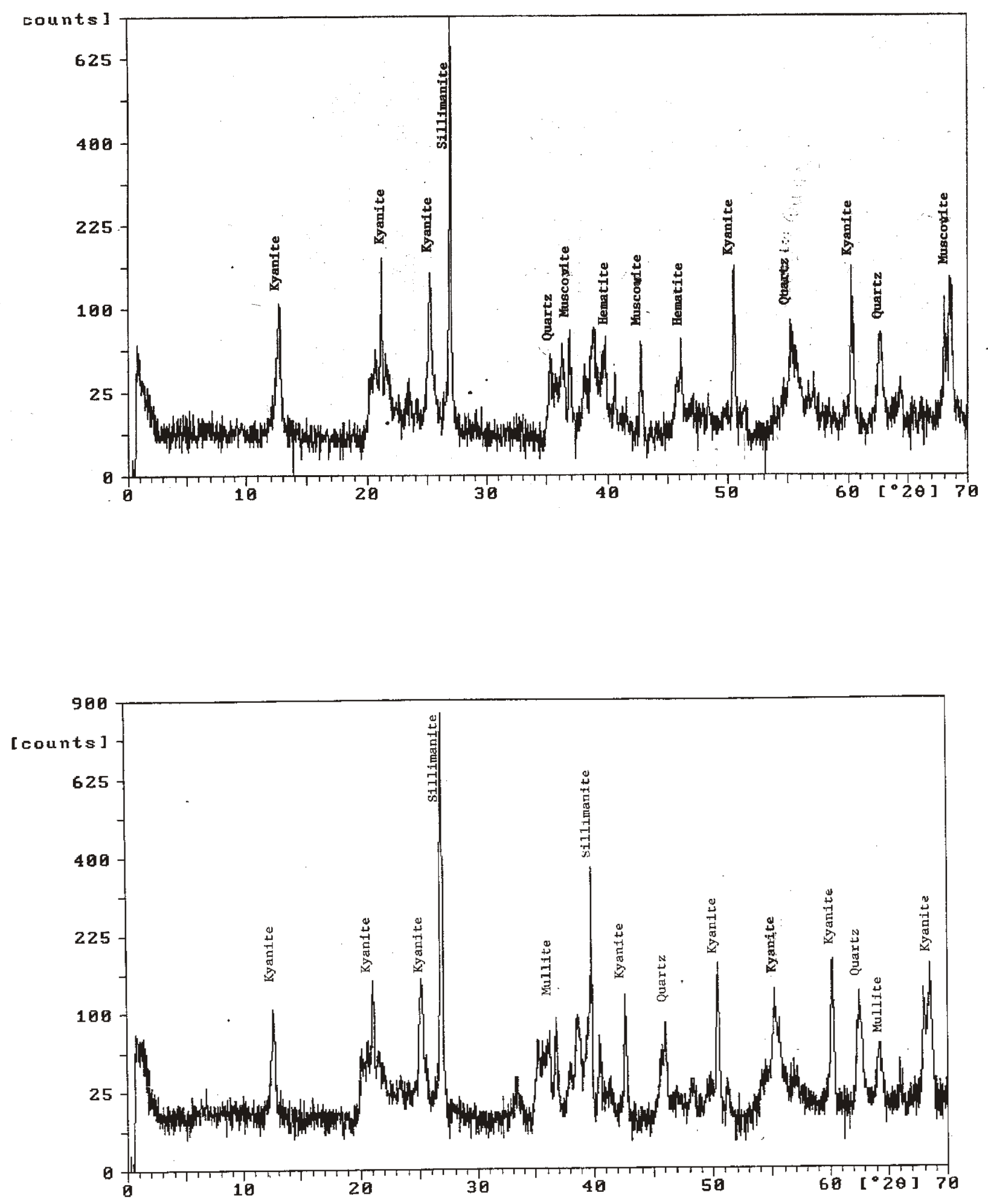

Fig. 2 Diffractograms of raw and beneficiated studied kyanite-quartzite 